\title{
Venous Thromboembolic Disease in Chronic Inflammatory Lung Diseases: Knowns and Unknowns
}

\author{
George Keramidas ${ }^{1}$, Konstantinos I. Gourgoulianis ${ }^{1}$ (D) and Ourania S. Kotsiou ${ }^{1,2, *}$ \\ 1 Department of Respiratory Medicine, Faculty of Medicine, University of Thessaly, BIOPOLIS, \\ 41110 Larissa, Greece; gkeramidas10@gmail.com (G.K.); kgourg@med.uth.gr (K.I.G.) \\ 2 Faculty of Nursing, School of Health Sciences, University of Thessaly, GAIOPOLIS, 41110 Larissa, Greece \\ * Correspondence: okotsiou@uth.gr; Tel.: +30-2413-502-812
}

Citation: Keramidas, G.;

Gourgoulianis, K.I.; Kotsiou, O.S.

Venous Thromboembolic Disease in

Chronic Inflammatory Lung Diseases: Knowns and Unknowns. J. Clin. Med. 2021, 10, 2061. https://doi.org/ $10.3390 / \mathrm{jcm} 10102061$

Academic Editor:

Ferdinando Mannello

Received: 20 March 2021

Accepted: 7 May 2021

Published: 11 May 2021

Publisher's Note: MDPI stays neutral with regard to jurisdictional claims in published maps and institutional affiliations.

\begin{abstract}
Persistent inflammation within the respiratory tract underlies the pathogenesis of numerous chronic pulmonary diseases. There is evidence supporting that chronic lung diseases are associated with a higher risk of venous thromboembolism (VTE). However, the relationship between lung diseases and/or lung function with VTE is unclear. Understanding the role of chronic lung inflammation as a predisposing factor for VTE may help determine the optimal management and aid in the development of future preventative strategies. We aimed to provide an overview of the relationship between the most common chronic inflammatory lung diseases and VTE. Asthma, chronic obstructive pulmonary disease, interstitial lung diseases, or tuberculosis increase the VTE risk, especially pulmonary embolism (PE), compared to the general population. However, high suspicion is needed to diagnose a thrombotic event early as the clinical presentation inevitably overlaps with respiratory disorders. PE risk increases with disease severity and exacerbations. Hence, hospitalized patients should be considered for thromboprophylaxis administration. Conversely, all VTE patients should be asked for lung comorbidities before determining anticoagulant therapy duration, as those patients are at increased risk of recurrent PE episodes rather than DVT. Further research is needed to understand the underlying pathophysiology of in-situ thrombosis in those patients.
\end{abstract}

Keywords: immunothrombosis; in situ thrombosis; lung diseases; pulmonary embolism; venous thromboembolism

\section{Introduction}

Pulmonary embolism (PE) and deep vein thrombosis (DVT) are clotting disorders collectively named venous thromboembolism (VTE), constituting the third most frequent acute cardiovascular syndrome [1]. PE most frequently occurs as a result of DVT of the lower extremities. PE's annual incidence ranges between 39 and 115 per 100,000 of the population [1]. Annual incidence for DVT ranges from 53 to 162 per 100,000 population [1]. Many studies support the notion that the VTE incidence showed a clear upward trend since the end of the 20th century when computed tomography pulmonary angiogram (CTPA) was introduced as an alternative to ventilation/perfusion scanning (V/Q scan) [2]. On the other hand, mortality seems to have a decreasing tendency since then at about 6,5 deaths per 100,000 population in 2015, according to data from the World Health Organization (WHO) Mortality Database [3].

Although several risk factors result in VTE, no risk factor can be identified in a third to half of VTE events [4], VTE is categorized as unprovoked in these cases, determining the duration of the anticoagulation therapy. Patients with no identifiable provoking factors for VTE may have individual risk factors that are rarely sufficient by themselves to predispose to a VTE episode. However, combinations thereof should be carefully reviewed to assess the overall risk of VTE in each patient.

Despite the close links and common evolutionary origin of inflammation and thrombosis, these pathways are mainly viewed separately [5]. However, inflammation and 
coagulopathy are tightly connected. Emerging evidence suggests that chronic inflammation may be a cause, as well as a consequence of VTE. The underlying mechanisms associated with chronic inflammation-associated coagulopathy have been suggested but not clearly defined.

It is helpful to conceptualize inflammation and thrombosis as interconnected not only from a basic science perspective but also from a clinical perspective [5]. Pulmonary thrombosis may not always result from embolization of a peripheral clot to the pulmonary arteries. Immunothrombosis normally facilitates the entrapment and disposal of pathogens and cellular debris. It is a phenomenon triggered by pathogens or cellular debris in inflammation, leading to thrombus formation [6]. However, once getting beyond control, it contributes to the formation of thrombus in situ. Evidence supports that patients with lung inflammatory diseases are at great risk of thrombosis directly in the lung's vasculature. In these cases, there is an activation of endothelial cells, platelets, and leukocytes with subsequent microparticles forming that can trigger the coagulation system through the induction of tissue factor (TF) [7]. Clot formation also results from the excretion of neutrophil extracellular traps (NETs) by neutrophils. NETs can activate factor (F) VII and TF, bind to von Willebrand factor (vWF), activate platelets via $\mathrm{H} 3$ and $\mathrm{H} 4$ histones, and locally concentrate enzymes such as neutrophil elastase and myeloperoxidase which cleave and inactivate TF pathway inhibitor (TFPI) and thrombomodulin [6], triggering immunothrombosis. Moreover, through largely overlapping pathways, and with the possible additional mediation of agent-specific virulence factors or autoantibodies, infection by both viruses [8] and bacteria [9], to which patients with chronic and acute respiratory disease are particularly vulnerable, has been postulated to cause local or systemic thrombophlebitis.

Transendothelial migration, an increase in the expression of endothelial adhesion molecules and in the percentage of senescent endothelial cells, vascular atrophy due to endothelial apoptosis, vascular remodeling and dysfunctional endothelial tissue are upregulated in chronic obstructive lung diseases depending on the phenotype of the patient [10-12]. These are likely to play a role in the increased influx of inflammatory cells seen in these chronic obstructive lung diseases [10-14], constituting parallel pathogenetic mechanisms involved in de novo VTE [10-12]. Moreover, the endothelial-to-mesenchymal transition is a precursor to IPF and vascular obliteration [14,15], as this change of endothelial phenotype may increase the vascular responses to thrombosis, decrease permeability control, and increase fibrotic reactions [14,15].

Persistent inflammation within the respiratory tract underlies the pathogenesis of numerous chronic pulmonary diseases [16]. However, the relationship between lung diseases and/or lung function with VTE is unclear. Understanding the role of chronic lung inflammation as a predisposing factor for VTE may not only help determine the optimal management, but may also aid in the development of future preventative strategies. This review aimed to provide an overview of the available evidence regarding the relationship between the most common chronic inflammatory lung diseases with VTE.

\section{Asthma and VTE}

Asthma is a chronic inflammatory airway disease [17]. The reversibility of airway limitation and inflammation in asthma patients has long been challenged. Asthma has been associated with enhanced procoagulant and antifibrinolytic activities in the airways [18-22], which derive from TF overexpression mechanisms, reduced anticoagulant protein $\mathrm{C}$ system activity, and inhibition of fibrinolysis through over-production of plasminogen activator inhibitor type 1 (PAI-1).

A great deal of previous research has focused on the association between asthma and PE. Majoor et al. reported that severe asthma is an independent risk factor for PE, but not for DVT [23] (Table 1). However, this concept has been challenged by several studies reporting an increased risk of both PE and DVT in asthma patients, a discrepancy in results likely related to different sample sizes [24]. More recently, Zöller et al. [24] studied 114,366 Swedish-born patients with a first hospital diagnosis of PE, 76,494 patients 
with DVT and 6854 patients with both PE and DVT in comparison with age-, gender-and educational attainment-matched controls for each case, between 1981 and 2010. The authors showed that asthma increases the risk for PE, isolated DVT, or both [24]. Specifically, it was reported that the adjusted odds ratio (OR) was 1.4 (95\% CI 1.4-1.5) for PE, 1.6 (95\% CI 1.5-1.7) for DVT, and 1.6 (95\% CI 1.3-2.0) for both entities in asthma patients compared to healthy individuals (Table 1). Earlier, a nationwide cohort study by Chung et al. [9] showed that the overall incidence rate of $\mathrm{PE}$ was three times higher in 31,356 patients with newly diagnosed asthma compared to 125,157 non-asthmatic individuals (10.2 versus 3.1 per 100,000 person-years). The overall hazard ratio (HR) of PE in asthmatic patients was 3.2 (95\% CI 1.7-6.0), after adjusting for sex, age, comorbidities, and estrogen use (Table 1).

Interestingly, the risk for thromboembolism increased with a recent history of a diagnosis of asthma [24]. According to Chung et al., the adjusted HR for PE (after adjusting for sex, age, comorbidities, and estrogen use) was 3.4 (95\% CI 1.7-6.7) during the first five years after diagnosing asthma [17] (Table 1).

A gender-related difference in PE prevalence has been reported, with males having a 3.2-fold increased risk of PE than females [17]. Asthmatic patients were at increased risk for PE across all age groups than non-asthmatic individuals, which increased even further with age increase [17]. Contradictory data are also presented showing that the OR declined with the increase of age [24]. In particular, it has been found that the OR for PE and DVT decreased from 2.2 (95\% CI 1.9-2.6) and 2.0 (95\% CI 1.7-2.4) for patients younger than 50 years of age to 1.5 (95\% CI 1.4-1.6) and 1.6 (95\% 1.4-1.7) for patients older than 75, respectively [24], but no age-specific statistical interaction in the group with $\mathrm{PE}$ and DVT was found. This finding is intriguing, considering that age is the strongest independent risk factor for VTE in the general population. Potential sources of bias for the study were that higher than the $91 \%$ of the VTE study group were older than 50 years old, $2.3 \%$ and $2.4 \%$ of the PE and DVT groups, respectively had asthma but with incomplete measures of asthma, as reported, mild asthma was not recorded, while the presence of residual and unmeasured confounding factors could not be excluded [24]. The same study reported more PE cases in older ages and that DVT was relatively more common at younger ages, but asymptomatic PE frequently occurs among DVT cases and asymptomatic DVT frequently occurs in PE cases [24]. In addition, Majoor et al. [23] reported a ninefold or a 3.5-fold increased risk of PE in patients with severe asthma or mild-moderate asthma compared to the general population, respectively. Interestingly, the use of systemic corticosteroids seemed to increase the risk of VTE, as stated by Johannesdottir et al. [25] and Stuijver et al. [26]. Because these effects were adjusted for indicators of severity of underlying disease [25], or for age; sex; hospitalizations (for malignancy, pregnancy, trauma, surgery, inflammatory bowel disease, inflammatory athritides, chronic respiratory failure); and use of anticoagulants, drugs for respiratory diseases, antibiotics, antidepressants, hormone replacement therapy, and oral contraceptives within $90 \mathrm{~d}$ prior to the index date [26], and existed also for noninflammatory conditions [25], these results are unlikely to be explained by confounding by indication. 
Table 1. Characteristics of studies included in this review regarding the relationship between asthma and venous thromboembolic disease (VTE).

\begin{tabular}{|c|c|c|c|c|c|c|c|c|}
\hline Study & Type of Study & Timeframe & Population & VTE Incidence Rate & $\begin{array}{l}\text { Standardized Rate } \\
\text { Ratio for VTE }\end{array}$ & $\begin{array}{l}\text { Adjusted Odds } \\
\text { Ratio for VTE }\end{array}$ & $\begin{array}{l}\text { Adjusted Hazard } \\
\text { Ratio for VTE }\end{array}$ & $\begin{array}{c}\text { Estimated Time } \\
\text { of Risk VTE }\end{array}$ \\
\hline \multirow{3}{*}{$\begin{array}{l}\text { Zöller et al., } \\
2017 \text { [24] }\end{array}$} & \multirow{3}{*}{$\begin{array}{l}\text { Nationwide } \\
\text { case-control } \\
\text { retrospective } \\
\text { study }\end{array}$} & \multirow{3}{*}{ 1981-2010 } & \multirow{3}{*}{$\begin{array}{l}\text { 114,366 Swedish-born asthma } \\
\text { patients with hospital PE } \\
\text { diagnosis, } \\
76,494 \text { asthma patients with } \\
\text { DVT, } 6854 \text { asthma patients } \\
\text { with both PE and DVT } \\
\text { Age-, gender-and eductional } \\
\text { attainment matched controls } \\
\text { for each case }\end{array}$} & \multirow{3}{*}{ Not provided } & \multirow{3}{*}{ Not provided } & $\begin{array}{l}\text { PE: } 1.4(95 \% \text { CI } \\
1.4-1.5)^{*}\end{array}$ & \multirow{3}{*}{ Not provided } & \multirow{3}{*}{ 1981-2010 } \\
\hline & & & & & & $\begin{array}{l}\text { DVT: } 1.6(95 \% \text { CI } \\
1.5-1.7)^{*}\end{array}$ & & \\
\hline & & & & & & $\begin{array}{l}\text { Combined PE/DVT: } \\
1.6(95 \% \text { CI 1.3-2.0)* } \\
* \text { adjusted for } \\
\text { comorbidities }\end{array}$ & & \\
\hline \multirow[b]{2}{*}{$\begin{array}{l}\text { Chung et al., } \\
2014 \text { [17] }\end{array}$} & \multirow[b]{2}{*}{$\begin{array}{l}\text { Nationwide- } \\
\text { population } \\
\text { retrospective } \\
\text { study }\end{array}$} & \multirow[b]{2}{*}{$2002-2008$} & \multirow[b]{2}{*}{$\begin{array}{l}31,356 \text { patients with newly } \\
\text { diagnosed asthma, } \\
125,157 \text { age- and } \\
\text { gender-matched } \\
\text { nonasthmatics }\end{array}$} & \multirow[b]{2}{*}{ Not provided } & \multirow[b]{2}{*}{$\begin{array}{l}\text { PE: } 3.3(95 \% \text { CI } \\
\text { 3.2-3.4) }\end{array}$} & \multirow[b]{2}{*}{ Not provided } & $\begin{array}{l}\text { PE: } 3.2(95 \% \text { CI } \\
1.7-6.0)^{*}\end{array}$ & $\begin{array}{l}\text { Until the end of } \\
2010\end{array}$ \\
\hline & & & & & & & $\begin{array}{l}\text { PE: } 3.4(95 \% \text { CI } \\
1.7-6.7) * \\
* \text { adjusted for sex, } \\
\text { age, comorbidities } \\
\text { and estrogen use }\end{array}$ & $\begin{array}{l}\text { During the first } \\
5 \text { years after } \\
\text { asthma } \\
\text { diagnosis }\end{array}$ \\
\hline \multirow{2}{*}{$\begin{array}{l}\text { Majoor et al., } \\
2013[23]\end{array}$} & \multirow{2}{*}{$\begin{array}{l}\text { Prospective } \\
\text { study }\end{array}$} & \multirow{2}{*}{$\begin{array}{l}1 \text { December } \\
2010-1 \text { May } \\
2011\end{array}$} & \multirow{2}{*}{$\begin{array}{l}648 \text { asthma patients } \\
\text { (283 severe and } \\
365 \text { mild-to-moderate asthma } \\
\text { patients) visiting outpatient } \\
\text { asthma clinics }\end{array}$} & $\begin{array}{l}\text { PE: Severe asthma: } 0.9(95 \% \mathrm{CI} \\
0.4-1.4) \text { per } 1000 \text { person-years } \\
\text { Mild-to-moderate asthma: } 0.3 \\
(95 \% \text { CI } 0.1-0.6) \text { per } \\
1000 \text { person-years } \\
\text { General population: } 0.2(95 \% \text { CI } \\
0.0-0.3) \text { per } 1000 \text { person-years }\end{array}$ & $\begin{array}{l}\text { PE: Severe asthma: } \\
8.9 \text { ( } 95 \% \text { CI } 4.6-15.6) \\
\text { Mild to moderate } \\
\text { asthma: } \\
4.0(95 \% \text { CI } 1.0-9.1)\end{array}$ & \multirow{2}{*}{ Not provided } & $\begin{array}{l}\text { PE: Severe asthma: } \\
3.3(95 \% \text { CI 1.2-9.9) }\end{array}$ & \multirow{2}{*}{$\begin{array}{l}\text { Mean risk time: } \\
39 \text { years (range } \\
20-63 \text { years) }\end{array}$} \\
\hline & & & & $\begin{array}{l}\text { DVT: } \\
\text { Severe asthma: } 0.4(95 \% \mathrm{CI} \\
0.0-0.7) \text { per } 1000 \text { person-years, } \\
\text { Mild to moderate asthma: } 0.6 \\
\text { (95\% CI 0.3-1.0) per } \\
1000 \text { person-years } \\
\text { General population: } \\
0.3 \text { ( } 95 \% \text { CI } 0.1-0.5) \text { per } \\
1000 \text { person-years }\end{array}$ & $\begin{array}{l}\text { DVT: Severe asthma; } \\
1.6 \text { ( } 95 \% \text { CI 0.4-4.1) } \\
\text { Mild to moderate } \\
\text { asthma: } 1.5(95 \% \text { CI } \\
0.3-4.2)\end{array}$ & & $\begin{array}{l}\text { DVT: was not } \\
\text { associated with } \\
\text { asthma }\end{array}$ & \\
\hline
\end{tabular}

Abbreviations: CI, confidence intervals; DVT, deep vein thrombosis; PE, pulmonary disease; VTE, venous thromboembolic disease. 
According to the study of Alzghoul et al. [27], the prevalence of PE was $19.1 \%$ in patients during an asthma exacerbation. An unambiguous relationship between the frequency of emergency department visits because of asthma exacerbations and PE incidence has been stated [24]. Chung et al. supported that the adjusted HR for PE increased from 1.0 (95\% CI 0.3-2.9) for those having two or fewer visits to 9.0 (95\% 4.3-18.9) for those with four or more visits [9]. Similarly, Zöller et al. found that the OR for PE shaping from 1.3 (95\% CI 1.3-1.4) for one to two hospital admissions to 1.4 (95\% CI 1.3-1.6) for three or four admissions and 1.82 for more than four hospital admissions [24]. However, it is unclear whether PE triggers bronchospasm, rendering itself the causative factor of the exacerbation.

Besides, the asthma patients diagnosed with PE had a longer hospitalization period and were transferred more frequently to the intensive care unit (ICU) than asthma patients without PE, while the mortality rate of asthma exacerbation patients with an acute PE has been reported to be $4 \%$ [27]. Several risk factors associated with the development of an acute PE during an asthma exacerbation have been recognized, including the following in descending order: a previous history of PE, the high CHA2DS2-VASc score on admission that estimates the bleeding and thrombotic risk, the simultaneous presence of hyperlipidemia, a previous history of DVT, the presence of cancer, the previous use of systemic corticosteroids, the obesity, and the medical history of atrial fibrillation [27]. Based on these factors, a predictive score for PE during an asthma exacerbation has been recently developed with an average predictive accuracy reaching 88\% [27]. Asthmatic patients with diabetes did not show an increased risk for PE [17].

Sneeboer et al. [28] compared coagulation parameters between healthy subjects and mild, severe or prednisolone-dependent asthma patients. The study showed significantly higher levels of endogenous thrombin potential (ETP), plasmin-antiplasmin complexes (PAPc), PAI-1, and vWF in the peripheral blood of asthmatic patients compared to healthy subjects. The prothrombotic state was even more intense with increasing asthma severity. A positive correlation between ETP or VWF and peripheral blood neutrophil counts was found, but not with eosinophilic counts.

In conclusion, several studies showed that asthma increases the risk for PE. Gender and age-related differences in PE prevalence have been reported. PE incidence is linked to asthma severity. Asthma patients with PE had a longer hospitalization and ICU stay period. However, the pathophysiological mechanisms are still not yet fully understood. It is considered that inflammation plays a major role by altering the balance between procoagulant and fibrinolytic agents. The prothrombotic state is related to increasing asthma severity, the number of exacerbations and hospitalizations, and the longer duration of hospitalization.

\section{Chronic Obstructive Pulmonary Disease and VTE}

COPD is characterized by persistent respiratory symptoms and airflow limitation due to airway and / or alveolar abnormalities caused by noxious gases or particles, influenced by host factors like abnormal lung development [29]. The airflow limitation occurs by a mixture of small airway disease and lung parenchyma destruction [29]. Respiratory infections cause about $50-70 \%$ of COPD exacerbations, $10 \%$ percent are caused by environmental pollution, and up to $30 \%$ of COPD exacerbations have no clear etiology [30].

People with poor lung function are at increased atherothrombotic risk. COPD, even in the stable phase, is considered to be an independent risk factor for PE. Systemic inflammation is the main atherothrombotic abnormality in COPD, but hypoxia-related platelet activation, pro-coagulant status, and oxidative stress may play a role [31-33]. Interestingly, Factor V Leiden homozygosity has been previously associated with severe dyspnea and decreased pulmonary function [33]. After adjustment for VTE risk factors, it has been reported that obstructive spirometric patterns (HR 1.3, 95\% CI 1.1-1.7), and not restrictive spirometric patterns (HR 1.2, 95\% CI 0.8-1.6), were associated with an increased risk of VTE. These results provided by a prospective cohort study by Kubota et al. included projecting 22 to 24 years risk from baseline spirometry diagnosis [32]. In contrast, other 
studies supported atherothrombosis in people with restrictive spirometric dysfunction that is attributed to systemic inflammation [33].

Similar to asthma, chronic inflammation contributes to the pathogenesis of COPD. An increase of C-reactive protein, fibrinogen, interleukin (IL)-6, IL-8 and tumor necrosis factora, hypoxemia, oxidative stress, and endothelial dysfunction may alter the coagulation profile by increasing PAI-1 and decreasing prostacyclin release [34].

VTE risk seems to be elevated in patients with acute exacerbation (AE) of COPD. A previous systematic review and meta-analysis by Rizkallah et al. found an estimated prevalence of PE of 19.9\% (95\% CI 6.7-33.0) among patients who did and did not require hospitalization, while they proposed that one of four COPD patients who require hospitalization for an acute exacerbation might have PE [35] (Table 2). Lately, Pourmand et al. supported that the prevalence of PE varies considerably in relation to the study setting, ranged from $3.3 \%$ to $29.1 \%$ in patients with a clinical diagnosis of AE-COPD [36] (Table 2). Bed resting, patient's comorbidities, and advanced age contribute to that as well [37]. AEs are associated with increased inflammation, hence enhanced thrombotic risk. In particular, according to Aleva et al. [37], PE prevalence was 16.1\% (95\% CI 8.3-25.8) during an AE of COPD in a total of 880 patients while DVT prevalence was 10.5\% (95\% CI 4.3-19.0) in a total of 831 patients (Table 2). More recent results by Dentali et al. [38] revealed a PE prevalence of $12.7 \%$ (95\% CI 10.7-14.8) among 1043 patients hospitalized with AE-COPD and suspected PE, a DVT prevalence of $6.4 \%$ (95\% CI 5.0-8.1) among 178 patients who were tested with compression ultrasound. The authors reported an isolated DVT prevalence of $2.7 \%$ (41.8\% of the DVT cases) among the whole study population. However, compression ultrasound was not used to confirm a diagnosis of DVT in all patients but only in 178 patients with signs of DVT [38]. Although DVT is usually twice as frequent as PE in the general population, PE seems to be the most frequent clinical presentation of VTE in patients with AE of COPD [39] (Table 2). Hence, according to the Global Initiative for Chronic Obstructive Lung Disease (GOLD) recommendations [21] and American College of Chest Physicians (ACCP) guidelines [40], thromboprophylaxis should be applied to hospitalized patients with severe COPD exacerbation given the high VTE risk. Nevertheless, VTE events might occur despite thromboprophylaxis during an AE of COPD [34]. 


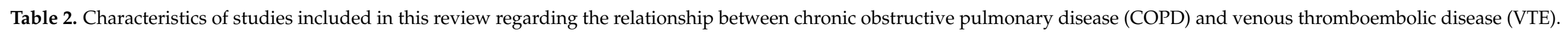

\begin{tabular}{|c|c|c|c|c|c|c|}
\hline Study & Type of Study & Timeframe & Population & Prevalence of VTE & Relative Risk & Estimated Time of Risk \\
\hline \multirow[b]{2}{*}{ Dentali et al., 2020 [38] } & \multirow{2}{*}{$\begin{array}{l}\text { Multicenter retrospective } \\
\text { cohort study }\end{array}$} & \multirow[b]{2}{*}{$\begin{array}{l}1 \text { January 2011- } \\
31 \text { December } 2011\end{array}$} & \multirow[b]{2}{*}{$\begin{array}{l}1043 \text { patients with an AE-COPD and } \\
\text { suspected PE }\end{array}$} & PE: $12.7 \%$ (95\% CI 10.7-14.8) & Not provided & \multirow[b]{2}{*}{ Not provided } \\
\hline & & & & $\begin{array}{l}\text { DVT: } 6.4 \% \text { (95\% CI 5.0-8.1) } \\
\text { (among } 178 \text { patients tested) }\end{array}$ & Not provided & \\
\hline Hassen et al., 2020 [30] & Prospective cohort study & March 2013-May 2017 & $\begin{array}{l}131 \text { patients with } \mathrm{AE}-\mathrm{COPD} \\
\text { requiring mechanical } \\
\text { ventilation }\end{array}$ & PE: $13.7 \%$ & Not provided & Not provided \\
\hline Pourmand et al., 2018 [36] & Systematic review & 1990-2017 & $\begin{array}{l}\text { Sample sizes of } 5 \\
\text { studies ranged from } 49-197 \text { patients } \\
\text { admitted to the hospital with a } \\
\text { clinical diagnosis of AE-COPD }\end{array}$ & $\begin{array}{l}\text { PE: } 3.3-29.1 \% \text { according to } \\
\text { the study setting }\end{array}$ & Not provided & Not provided \\
\hline \multirow[b]{2}{*}{ Aleva et al. 2017 [37] } & \multirow[b]{2}{*}{$\begin{array}{l}\text { Systematic review and } \\
\text { meta-analysis }\end{array}$} & \multirow[b]{2}{*}{ 1974-October 2015} & \multirow[b]{2}{*}{$\begin{array}{l}880 \text { patients with AE-COPD } \\
\text { admitted or hospitalized ( } 7 \text { studies) }\end{array}$} & PE: 16.1\% (95\% CI 8.3-25.8) & Not provided & \multirow[b]{2}{*}{ Not provided } \\
\hline & & & & $\begin{array}{l}\text { DVT: } 10.5 \%(95 \% \text { CI } \\
4.3-19.0) \text { (among } \\
831 \text { patients) }\end{array}$ & Not provided & \\
\hline \multirow{2}{*}{ Park et al., 2016 [41] } & \multirow{2}{*}{ Retrospective study } & \multirow{2}{*}{ January 2011-December 2011} & \multirow{2}{*}{$\begin{array}{l}15,686 \text { COPD patients } \\
859 \text { ILD patients } 640,177 \text { general } \\
\text { population and } 7280 \text { CTD patients }\end{array}$} & PE: 11.3 (95\% CI 9.6-13.2) & \multirow{2}{*}{ Not provided } & \multirow{2}{*}{ One year risk } \\
\hline & & & & DVT: 4.8 (95\% CI 3.9-5.9) & & \\
\hline Gunen et al., 2010 [42] & Prospective cohort study & & 131 patients with AE-COPD & PE: 13.7\% (95\% CI 7.8-19.6) & $2.528(95 \%$ CI & One year risk \\
\hline \multirow{2}{*}{ Rizkallah et al., 2009 [35] } & \multirow{2}{*}{$\begin{array}{l}\text { Systematic review and } \\
\text { meta-analysis }\end{array}$} & \multirow{2}{*}{ 1949-April 2008} & \multirow{2}{*}{$\begin{array}{l}550 \text { patients who did and did not } \\
\text { require hospitalization ( } 5 \text { studies) }\end{array}$} & $\begin{array}{l}\text { PE: } 19.9 \% \text { (95\% CI } 6.7-33.0) \\
\text { of the whole study group }\end{array}$ & Not provided & \multirow{2}{*}{ Not provided } \\
\hline & & & & $\begin{array}{l}\text { PE: } 24.7 \%(95 \% \text { CI } 17.9-31.4) \\
\text { in hospitalized patients }\end{array}$ & Not provided & \\
\hline
\end{tabular}

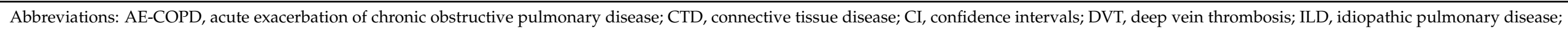

PE, pulmonary disease; VTE, venous thromboembolic disease. 
Dentali et al. supported that except from the signs and symptoms of DVT (OR: 4.4, 95\% CI 2.7-7.4), the presence of a normal chest x-ray (OR: 2.0, 95\% CI 1.3-3.1), the partial pressure of carbon dioxide (pCO2) less than $40 \mathrm{mmHg}$ (OR: 1.5, 95\% CI 1.0-2.3), hypertension (OR: 1.5, 95\% CI 1.0-2.3), and the increasing age (OR: 1.03, 95\% CI 1.01-1.06) and the female gender have been associated with higher PE prevalence in COPD patients [38]. Interestingly, the number of the patient's coexisting risk factors $(0,1,2,3, \geq 4)$ was positively correlated with a progressive increase in PE prevalence from 1.8 to $30.4 \%$ [38]. This accounts for a decrease of 57 CTPAs needed to diagnose one PE with no risk factors to three CTPAs for a PE diagnosis in a COPD patient with four risk factors. The same study found that PE prevalence was lower in patients with active cancer and patients with purulent sputum [38]. Furthermore, pleuritic chest pain and cardiac failure were more frequent in AE-COPD patients with PE, while respiratory tract infection was less frequently observed in PE patients than non-PE COPD patients [34,37]. Akpinar et al. [43] reported that pleuritic chest pain appears twice more frequently in PE patients. Therefore, identifying the presence and aggregation of the aforementioned parameters may be useful before performing CTPA on patients during an AE of COPD with suspected PE [38].

Regarding ICU patients, the prevalence of PE incidence has been reported to be $13.7 \%$, according to Hassen et al. [30] (Table 2). Increased sputum volume (OR: 0.1, 95\% CI $0.0-0.4, p=0.001$ ), recent immobilization for seven days or more (OR: 5.0, 95\% CI 1.5-17.2, $p=0.01$ ), age 70 years or more (OR: $5.5,95 \%$ CI $1.3-23.7, p=0.02$ ), and invasive mechanical ventilation (OR: 3.6, 95\% CI 1.0-13.0, $p=0.049$ ) were independently positively associated with concomitant $\mathrm{PE}$ events in AE-COPD patients required mechanical ventilation [30]. Nadroparin prophylaxis in mechanically ventilated patients due to acute COPD resulted in a $45 \%$ decrease of VTE compared to placebo, with no difference in adverse events [44].

Some challenges might appear while diagnosing PE in COPD patients. Dentali et al. [38] noted that the accuracy of clinical probability scores like Wells and Geneva score needs to be validated in COPD patients. Especially in Wells score, the subjective variable "alternative diagnosis more likely than $\mathrm{PE}^{\prime \prime}$ is quite difficult to be assessed by physicians in $\mathrm{AE}$ of COPD where the symptoms of both diseases overlap. D-dimer testing is a tool used to exclude PE, but d-dimers may also increase due to inflammation during acute exacerbations. Gunen et al. [42] reported that $95 \%$ of hospitalized patients for AE COPD with VTE had increased d-dimer levels above $500 \mu \mathrm{g} / \mathrm{L}$. At this cut-off level, the negative predictive value was 0.98 . The absence of respiratory infection symptoms and plasma D-dimer elevation above $500 \mu \mathrm{g} / \mathrm{L}$ were significant predictors of PE in patients with COPD exacerbation [45].

As far as CTPA is concerned, it has been supported that in severe AEs of COPD, DVT prevalence is lower than PE, suggesting that many PE cases were in situ thrombotic events rather than embolic events [37]. It is of great clinical significance that only $32.5 \%$ of PE events were diagnosed with isolated subsegmental emboli and the rest $68 \%$ were diagnosed with a thrombus localized at the segmental or more proximal level ( $35 \%$ in main pulmonary artery, $31.7 \%$ in lobar/interlobar arteries and $0.8 \%$ in the pulmonary trunk) [37]. Contradictory data are also present reported that emboli tend to lodge in more peripheral sites and are more likely to be unilateral and singular in COPD patients [46].

COPD patients with PE have a worse prognosis, as expected, with increased mortality and length of hospitalization [37]. Hassen et al. [30] reported that mortality was $44 \%$ in PE patients than $11 \%$ in non-PE COPD patients who admitted to ICU department due to an acute exacerbation. After adjusting for age, a COPD patient with PE had a seven-fold rise in the probability of death (OR: $7.1,95 \%$ CI $0.0-24.9, p=0.002$ ). In addition, the high simplified acute physiology score (SAPS II) (OR: 1.1,95\% CI 0.0-1.1, $p=0.020$ ) and prolonged mechanical ventilation (OR: $1.1,95 \%$ CI $0.0-1.2, p<0.001$ ) were independent predictors of nosocomial mortality [30]. On the other hand, in many cases, the risk of bleeding outweighs anticoagulation benefits, which placed a question mark in routinely using CTPA for screening. CTPA should rather be used in cases with atypical exacerbation symptoms such as pleuritic pain, signs of cardiac failure, absence of infectious origin, and VTE history [46]. 
Furthermore, up to $50 \%$ of COPD patients may present with pulmonary arterial hypertension (PAH) [47]. PAH is associated with hypercoagulability, leading to in situ thromboses [48]. There have been reported increased levels of von Willebrand factor, TF and PAI-1, and increased shear stress and platelet activation along with the increase of pressure in pulmonary arteries. Considering that $\mathrm{PAH}$ is disproportionately severe in $2-5 \%$ of all COPD patients [47], the risk of PE in these patients is even greater, as is the prognosis.

Data support that PE during COPD exacerbation is considered provoked, with the most frequent triggering factor being the immobilization due to acute medical illness [39]. Several theories suggest that the risk of VTE recurrence after stopping anticoagulation therapy is similar between COPD and non-COPD patients [49] and the clinical presentation of VTE recurrence to the first VTE event is similar in both groups, while no differences in risk of death after cessation of anticoagulation were found between the two groups. What is less clear is the short- and long-term thrombogenic status that remained after an $\mathrm{AE}$ of COPD.

In conclusion, COPD patients carry a high VTE risk that sets them in need of thromboprophylaxis during AE. A higher incidence of PE than DVT suggests that PE cases might occur as in situ thrombosis rather than embolic events. Diagnostic uncertainty could contribute to diagnostic errors. Thus, clinical probability scores and d-dimer testing should be used cautiously due to the overlap of symptoms between PE and COPD.

\section{Interstitial Lung Diseases and VTE}

Interstitial lung diseases (ILDs) are a group of diffuse parenchymal lung disorders resulting in high mortality rates. According to the 2013 classification update by the American Thoracic Society (ATS)/European Respiratory Society (ERS), ILDs are distinguished as major idiopathic interstitial pneumonias (IIPs) (idiopathic pulmonary fibrosis, idiopathic nonspecific interstitial pneumonia, respiratory bronchiolitis-interstitial lung disease, desquamative interstitial pneumonia, cryptogenic organizing pneumonia, acute interstitial pneumonia), rare IIPs (idiopathic lymphoid interstitial pneumonia, idiopathic pleuroparenchymal fibroelastosis) and unclassifiable IIPs [50]. The main representative of this heterogenous group is idiopathic pulmonary fibrosis (IPF), a chronic and progressive disease characterized by extracellular matrix deposition, resulting in lung remodeling. It represents about $20 \%$ of ILDs being the most common, carrying the worst prognosis amongst them [51].

An association between IPF and increased risk of thromboembolic events has been documented. The exact cause of the correlation between IPF and VTE is unknown but reduced mobility of patients experiencing symptoms like shortness of breath, fatigue and joint stiffness may predispose to VTE [52]. Additionally, a higher prevalence of pulmonary hypertension $(\mathrm{PH})$ observed in these patients leads to increased resistance of pulmonary arteries and blood stagnation [41], while increased angiogenic chemokines result in aberrant angiogenesis and endothelial abnormalities [53-55]. Another explanation might be a common pathogenetic pathway between IPF and VTE. This is supported by the findings of increased thrombin concentration in bronchoalveolar lavage of fibrotic lung disease patients [56], which is considered to be a potent inducer of fibrogenic cytokine generation such as transforming growth factor (TGF)- $\beta$, connective tissue growth factor (CTGF) and platelet-derived growth factor-AA [57]. These results are consistent with the study of Imokawa et al. [58] shown increased TF and fibrin depositions on type II pneumonocytes of patients with pulmonary fibrotic disease. Other studies reported decreased protein $C$ activation in IPF patients [59] and induction of TF and PAI-1 [60]. Navaratnam et al. [61] stated that a prothrombotic state in patients with IPF is almost five times higher (OR: 4.8, 95\% CI 2.9-7.8) and is associated with increased mortality (HR: 3.5, 95\% CI 1.1-9.8).

This procoagulant state elevates VTE risk. Sprunger et al. [62] reported that VTE prevalence in IPF decedents was $1.74 \%$ and $34 \%$ higher than in the general population (OR: 1.3, 95\% CI 1.3-1.4). They also reported that VTE prevalence in IPF decedents was higher than in COPD (OR: 1.4, 95\% CI 1.4-1.5) or lung cancer decedents (overall OR: 
1.5, 95\% CI 1.5-1.6) (Table 3). A previous study by Hubbard et al. supported that the risk of DVT was greater before (OR 2.0, 95\% CI 1.1-3.5) and even greater after (rate ratio 3.4, 95\% CI 1.6-7.3) the diagnosis of IPF in comparison to the general population [63] (Table 3). According to Dalleywater et al. [64] the prevalence of PE and DVT in IPF patients has been $2.4 \%$ (6-fold risk) and 1.1\% (2-fold risk), respectively. A meta-analysis by Boonpheng et al. [65] showed that the pooled risk ratio of VTE in IPF was 2.1 (95\% CI 1.3-3.5), while Margaritopoulos et al. [52] reviewed a VTE prevalence of $2 \%$ in IPF patients, two-fold higher than healthy individuals.

A Danish 27-year study by Sode et al., comprising 7.4 million individuals, estimated an adjusted HR of 2.4 (95\% CI 2.3-2.6) and 1.3 (95\% CI 1.2-1.4) for PE and DVT, respectively among IPF patients [66]. The same study also revealed an adjusted HR of 2.2 (95\% CI 2.1-2.3) and 1.4 (95\% CI 1.3-1.4) for PE and DVT in ILD patients (Table 3). Luo et al. [65] reported that among 57 patients with ILDs, 26.3\% had VTE [66]. In a retrospective cohort study by Park et al. [41] the prevalence rates for PE and DVT was 1746 (OR: 16.4, 95\% CI 9.7-27.4) and 582 (OR: 4.4,95\% CI 1.8-10.6) per 100,000 population, respectively, in ILD patients. The prevalence of PE in ILDs was similar to COPD and higher than the PE prevalence of the general population and patients with connective tissue diseases [41]. DVT prevalence was similar among the patient groups [41]. Interestingly PE/DVT ratio was 3.1 for ILD, 1.8 for COPD, 0.7 for CTD and 0.8 for the general population. This data suggests that there might be in situ thrombosis in pulmonary arteries or that the vascular beds are affected in ILD and COPD individuals, resulting in a delayed or no resolution of the clot, while the process is normally performed in the primary position of DVT [51].

Luo et al. also supported that symptoms like dyspnea (OR: 3.8, 95\% CI 1.1-12.8, $p=0.035$ ), lower extremity edema (OR: 8.7,95\%CI 1.8-41.4, $p=0.007$ ) and palpitations (OR: $4.8,95 \%$ CI 1.1-21.0, $p=0.040$ ), as well as d-dimer levels higher than $500 \mathrm{ng} / \mathrm{L}$ (OR: 5.1, 95\% CI 1.0-25.5, $p=0.048$ ) were associated with VTE events in patients with ILDs [67]. Concerning diagnosis, PE should be suspected when there is acute deterioration with simultaneously no imaging features in high resolution computed tomography (HRCT) or findings from serial lung function tests suggesting progression of ILD [52]. Respiratory symptoms due to ILD may interfere with the applicability of clinical probability scores, especially the Wells score, due to the subjective criterion [the physicians' judgment of whether an alternative diagnosis is less likely than PE]. However, the area under curve (AUC) for the diagnostic performance of Wells and Geneva scores was not significantly different in patients with ILDs (0.720 vs. 0.704) [67]. On the contrary, V/Q scan use should be limited because possible mismatch regions that would otherwise be diagnostic, correspond to honeycombing or emphysema [52].

In the general population, treatment of the acute phase of PE includes parenteral heparin with or without overlap with Vitamin K antagonists (VKA), or alternatively, the use of direct oral anticoagulants DOACs. Nevertheless, in IPF, warfarin has designated cautious use. In a randomized placebo-controlled trial, warfarin was associated with a lack of efficacy and increased mortality [68]. Margaritopoulos et al. [42] suggested that warfarin should be avoided in IPF, noting, however, that there has been no evidence against warfarin use in non-IPF ILDs. The prognosis of IPF patients becomes worse in the presence of VTE. There is no gender-related difference in mortality. Female patients with VTE died earlier (median age: 74.3 vs. 77.4 ) and the same as male patients with VTE (median age: 72 vs. 74.4) [62].

Sarcoidosis is a systemic inflammatory, granulomatous disease, mainly affecting lung parenchyma. It is associated with increased VTE prevalence as well. According to a metaanalysis by Ungprasert et al. [69] the pooled risk ratio of VTE in sarcoidosis was 1.4 (95\% CI 1.1-1.8), while in another study by Ungprasert et al. [69], the HR for VTE, DVT and PE was 3.0 (95\% CI 1.5-6.3), 3.1 (95\% CI 1.3-7.5), and 4.3 (95\% CI 1.2-15.2), respectively. After excluding the first six months following the index date of sarcoidosis diagnosis, to avoid surveillance bias due to more frequent thoracic imaging, the HR for VTE, DVT and PE were 2.7 (95\% CI, 1.3-5.7), 3.0 (95\% CI 1.3-7.2), and 3.6 (95\% CI 1.0-13.0), respectively [70]. 
Table 3. Characteristics of studies included in this review regarding the relationship between interstitial lung diseases (ILDs) and venous thromboembolic disease (VTE).

\begin{tabular}{|c|c|c|c|c|c|c|c|c|c|}
\hline Study & Type of Study & Timeframe & Population & Prevalence of VTE & $\begin{array}{l}\text { Adjusted Odds } \\
\text { Ratio for VTE }\end{array}$ & Rate Ratio for VTE & Risk Ratio for VTE & $\begin{array}{l}\text { Adjusted Hazard } \\
\text { Ratio for VTE }\end{array}$ & $\begin{array}{c}\text { Estimated Time of } \\
\text { Risk }\end{array}$ \\
\hline $\begin{array}{l}\text { Boonpheng et al., } \\
2018 \text { [65] }\end{array}$ & $\begin{array}{l}\text { Systematic review } \\
\text { and meta-analysis }\end{array}$ & $\begin{array}{l}\text { February } \\
2017-2018\end{array}$ & $\begin{array}{l}\text { Sample sizes of } 5 \\
\text { studies ranged from } \\
\text { 211-218,991 IPF patients }\end{array}$ & Not provided & Not provided & Not provided & $\begin{array}{l}\text { Pooled risk ratio: } 2.1 \\
\text { (95\% CI, 1.3-3.5) }\end{array}$ & Not provided & Not provided \\
\hline $\begin{array}{l}\text { Park et al., } 2016 \\
\text { [41] }\end{array}$ & $\begin{array}{l}\text { Retrospective } \\
\text { cohort study }\end{array}$ & $\begin{array}{l}\text { January 2011- } \\
\text { December } 2011\end{array}$ & $\begin{array}{l}859 \text { ILD patients } \\
640,177 \text { general population } \\
15,686 \text { COPD and } \\
7280 \text { CTD patients }\end{array}$ & Not provided & $\begin{array}{l}\text { DVT: } 4.4(95 \% \text { CI } \\
1.8-10.6)\end{array}$ & Not provided & Not provided & Not provided & One year risk \\
\hline \multirow[b]{2}{*}{$\begin{array}{l}\text { Dalleywater et al., } \\
2014 \text { [64] }\end{array}$} & \multirow[b]{2}{*}{$\begin{array}{l}\text { Prospective } \\
\text { database cohort } \\
\text { study }\end{array}$} & \multirow[b]{2}{*}{ 2000-2006 } & \multirow[b]{2}{*}{$\begin{array}{l}3211 \text { incident cases of } \\
\text { IPF-clinical syndrome and } \\
12,307 \text { matched controls }\end{array}$} & PE: $2.4 \%$ & \multirow[b]{2}{*}{ Not provided } & $\begin{array}{l}\text { PE: } 9.3(95 \% \mathrm{CI}, \\
\text { 7.4-11.7) }\end{array}$ & & Not provided & \multirow{2}{*}{$\begin{array}{l}\text { Median } \\
\text { (interquartile range) } \\
\text { follow-up after the } \\
\text { index date was } 1.7 \\
(0.6-3.6) \text { years in } \\
\text { cases and } 3.3 \\
\text { (1.5-5.8) years for } \\
\text { controls. }\end{array}$} \\
\hline & & & & DVT: $1.1 \%$ & & $\begin{array}{l}\text { DVT: } 4.3(95 \% \mathrm{CI} \\
3.0-6.0)^{*} \\
* \text { adjusted for matching } \\
\text { variables, smoking } \\
\text { habit and warfarin } \\
\text { prescription }\end{array}$ & $\begin{array}{l}\text { VTE: } 3.7(95 \% \text { CI, } \\
1.2-11.0)\end{array}$ & Not provided & \\
\hline $\begin{array}{l}\text { Sprunger et al., } \\
2012 \text { [62] }\end{array}$ & $\begin{array}{l}\text { Cross-sectional } \\
\text { study database } \\
\text { study }\end{array}$ & 1988-2007 & 218,991 records with IPF & VTE: $1.74 \%$ & $\begin{array}{l}\text { VTE: } 1.3(95 \% \text { CI } \\
1.3-1.4)^{*} \\
* \text { adjusted for age, } \\
\text { sex and year of } \\
\text { death }\end{array}$ & Not provided & $\begin{array}{l}\text { VTE: } 1.3(95 \% \text { CI, } \\
\text { 1.3-1.4) }\end{array}$ & Not provided & 1988-1998 \\
\hline \multirow{4}{*}{$\begin{array}{l}\text { Sode et al., } 2009 \\
\text { [66] }\end{array}$} & \multirow{4}{*}{$\begin{array}{l}\text { Retrospective } \\
\text { cohort }\end{array}$} & \multirow{4}{*}{ 1980-2007 } & \multirow{4}{*}{$\begin{array}{l}\text { 19,557 individuals with IPF } \\
\text { and } 34,493 \text { individuals with } \\
\text { ILDs } \\
\text { and } 7260,277 \text { controls }\end{array}$} & \multirow{4}{*}{ Not provided } & \multirow{4}{*}{ Not provided } & \multirow{4}{*}{ Not provided } & \multirow{4}{*}{ Not provided } & $\begin{array}{l}\text { IPF: PE } 2.4(95 \% \text { CI, } \\
\text { 2.3-2.6) }\end{array}$ & \multirow{4}{*}{ Not provided } \\
\hline & & & & & & & & $\begin{array}{l}\text { IPF: DVT: } 1.3(95 \% \\
\text { CI, 1.2-1.4) }\end{array}$ & \\
\hline & & & & & & & & $\begin{array}{l}\text { ILD: PE: } 2.2 \text { (95\% CI, } \\
\text { 2.1-2.3) }\end{array}$ & \\
\hline & & & & & & & & $\begin{array}{l}\text { ILD: DVT: } 1.4(95 \% \\
\text { CI, 1.3-1.4) }\end{array}$ & \\
\hline $\begin{array}{l}\text { Hubbard et al., } \\
2008 \text { [63] }\end{array}$ & $\begin{array}{l}\text { Comparative } \\
\text { retrospective and } \\
\text { prospective } \\
\text { database study }\end{array}$ & $1991-2003$ & $\begin{array}{l}920 \text { incident case } \\
\text { subjects of IPF and } 3593 \\
\text { matched control subjects }\end{array}$ & Not provided & $\begin{array}{l}\text { DVT: } 2.0 \text { ( } 95 \% \text { CI, } \\
1.1-3.5)^{*} \\
\text { * adjusted for age, } \\
\text { sex, smoking habit } \\
\text { and medications }\end{array}$ & Not provided & $\begin{array}{l}\text { VTE: } 3.4(95 \% \text { CI, } \\
1.6-7.3)\end{array}$ & Not provided & $\begin{array}{l}\text { Mean duration } \\
\text { before index date: } \\
7.8 \pm 3.9 \text { years for } \\
\text { case subjects } \\
\text { ( } 7.7 \pm 3.9 \text { years for } \\
\text { control subjects) }\end{array}$ \\
\hline
\end{tabular}

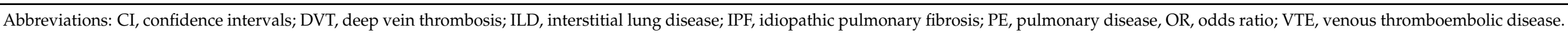


To conclude, patients with ILDs or sarcoidosis are at increased risk of VTE. In patients with ILDs and especially IPF, PE prevalence seems to be higher than DVT prevalence, given their potentially damaging effects directly to the lung parenchyma and vessels, leading to in-situ thrombotic events. Further research is needed regarding early diagnosis and treatment safety and efficacy concerning warfarin in patients with ILDs.

\section{Tuberculosis and VTE}

Tuberculosis (TB) is a bacterial disease caused by Mycobacterium Tuberculosis, part of the M. Tuberculosis complex. It is mainly an airborne infectious disease. Any organ can be affected by TB, but in HIV-negative individuals, the pulmonary disease is the most common clinical manifestation (70-80\% of cases) [71].

TB is an inflammatory disease associated with activation of the coagulation cascade. More specifically, increased levels of fibrinogen, factor VIII, PAI-1, and decreased antithrombin III and protein C levels have been reported in the plasma of TB patients [71,72]. Most of these parameters went back to normal on the thirtieth day of TB treatment [72,73]. In addition, studies showed that platelets are important players in the formation and function of granuloma and macrophage transformation in TB [74].

Many studies [75-77] suggested that the proinflammatory cytokines IL-1, IL-6 and tumor necrosis factor-alpha (TNF-a) are produced by mononuclear or macrophage cells during TB leading to increased thrombotic tendency and up-regulation of coagulation. Moreover, Mycobacterium Tuberculosis itself can induce TF expression through direct contact of bacteria with macrophages. TB is frequently associated with other chronic infections such as HIV infection and viral hepatitis. Hence, these patients may be at increased risk of thrombosis due to the aggregated inflammatory profile in case of coinfection [78]. In the study by Borjas-Howard et al. [78] HIV co-infection was independently associated with VTE (adjusted OR: 8.2, CI 95\% 2.9-22.7) (Table 4).

Far too little attention has been paid to the coagulation state of patients with latent tuberculosis infection (LTBI). Shitrit et al. found that patients with LTBI had normal d-dimer levels suggesting that low-level inflammations such as LTBI do not lead to a hypercoagulable state [79]. An increased abundance of vitamin K-dependent protein S (PROS) in both unstimulated and stimulated plasma samples in active TB as compared to LTBI suggests that only patients with TB are in a systemic hypercoagulable state [80].

Table 4. Characteristics of studies included in this review regarding the relationship between tuberculosis and venous thromboembolic disease (VTE).

\begin{tabular}{|c|c|c|c|c|c|c|}
\hline Study & Type of Study & Timeframe & Population & $\begin{array}{c}\text { Prevalence of } \\
\text { VTE }\end{array}$ & $\begin{array}{l}\text { Odds Ratio for } \\
\text { VTE }\end{array}$ & $\begin{array}{c}\text { Estimated Time } \\
\text { of Risk }\end{array}$ \\
\hline \multirow{3}{*}{$\begin{array}{l}\text { Danwang et al., } \\
2021 \text { [5] }\end{array}$} & \multirow{3}{*}{$\begin{array}{l}\text { Systematic review } \\
\text { and meta-analysis }\end{array}$} & \multirow{3}{*}{$\begin{array}{l}\text { Until } \\
15 \text { December } 2019\end{array}$} & \multirow{3}{*}{$\begin{array}{l}16,190 \text { partici- } \\
\text { pants ( } 9 \text { studies } \\
\text { included) }\end{array}$} & $\begin{array}{l}\text { VTE: } 3.5 \%(95 \% \\
\text { CI } 2.2-5.2) \\
16,190 \text { partici- } \\
\text { pants ( } 9 \text { studies } \\
\text { included) }\end{array}$ & $\begin{array}{l}\text { VTE: } 2.9(95 \% \text { CI } \\
2.3-3.7)\end{array}$ & \multirow{3}{*}{ Not provided } \\
\hline & & & & $\begin{array}{l}\text { PE: } 5.8 \%(95 \%) \mathrm{CI} \\
2.2-10.7) \\
6 \text { studies; } \\
5512 \text { participants }\end{array}$ & $\begin{array}{l}\text { PE: } 3.58(95 \% \text { CI } \\
2.5-5.1)\end{array}$ & \\
\hline & & & & $\begin{array}{l}\text { DVT: } 1.3 \%(95 \% \\
\text { CI 0.0-4.1) } \\
5 \text { studies; } \\
\text { 12,928 partici- } \\
\text { pants }\end{array}$ & $\begin{array}{l}\text { DVT: } 2.47(95 \% \text { CI } \\
1.8-3.4)\end{array}$ & \\
\hline $\begin{array}{l}\text { Borjas-Howard } \\
\text { et al., } 2017 \text { [78] }\end{array}$ & $\begin{array}{l}\text { Retrospective } \\
\text { study }\end{array}$ & 2000-2010 & 750 participants & $\begin{array}{l}2.4(95 \% \mathrm{CI} \\
1.4-3.8)\end{array}$ & $\begin{array}{l}\text { VTE in } \\
\text { HIV-positive: } 8.2 \\
(\text { CI 95\% 2.9-22.7) * } \\
\text { * Adjusted for } \\
\text { gender and } \\
\text { hospitalization }\end{array}$ & Not provided \\
\hline
\end{tabular}


Table 4. Cont.

\begin{tabular}{|c|c|c|c|c|c|c|}
\hline Study & Type of Study & Timeframe & Population & $\begin{array}{c}\text { Prevalence of } \\
\text { VTE }\end{array}$ & $\begin{array}{c}\text { Odds Ratio for } \\
\text { VTE }\end{array}$ & $\begin{array}{c}\text { Estimated Time } \\
\text { of Risk }\end{array}$ \\
\hline \multirow{3}{*}{$\begin{array}{l}\text { Dentan et al., } \\
2014 \text { [81] }\end{array}$} & \multirow{3}{*}{$\begin{array}{l}\text { Retrospective } \\
\text { database cohort } \\
\text { study }\end{array}$} & \multirow{3}{*}{$\begin{array}{l}1 \text { January 2006- } \\
31 \text { December } \\
2006\end{array}$} & \multirow{3}{*}{$\begin{array}{l}27,659,947 \mathrm{~TB} \\
\text { admissions }\end{array}$} & $\begin{array}{l}\text { VTE: } 2.1 \%(95 \% \\
\text { CI, } 1.6-2.6)\end{array}$ & \multirow{3}{*}{$\begin{array}{l}\text { VTE: } 1.55 \text { (95\% CI, } \\
1.2-2.0)\end{array}$} & \multirow{3}{*}{ One year risk } \\
\hline & & & & $\begin{array}{l}\text { PE: } 0.9 \%(95 \% \text { CI, } \\
0.7-1.3)\end{array}$ & & \\
\hline & & & & $\begin{array}{l}\text { DVT: } 1.1 \%(95 \% \\
\text { CI } 0.8-1.5)\end{array}$ & & \\
\hline \multirow{3}{*}{$\begin{array}{l}\text { Marjani et al., } \\
2012 \text { [82] }\end{array}$} & \multirow{3}{*}{ Prospective study } & \multirow{3}{*}{ 2007-2009 } & \multirow{3}{*}{1153 participants } & $\begin{array}{l}\text { VTE: } 2.8 \%(95 \% \\
\text { CI, } 1.9-3.9)\end{array}$ & \multirow{3}{*}{ Not provided } & \multirow{3}{*}{ Not provided } \\
\hline & & & & $\begin{array}{l}\text { PE: } 1 \%(95 \% \text { CI, } \\
0.5-1.7)\end{array}$ & & \\
\hline & & & & $\begin{array}{l}\text { DVT: } 2 \%(95 \% \text { CI, } \\
1.3-3)\end{array}$ & & \\
\hline
\end{tabular}

Abbreviations: CI, confidence intervals; DVT, deep vein thrombosis; PE, pulmonary disease, OR, odds ratio; VTE, venous thromboembolic disease.

Additionally, TB infection induces enlargement of lymph nodes that may result in compression of pulmonary veins, which in combination with patients' bed rest leads to the stagnation of blood [5]. Furthermore, it is suggested that rifampicin, part of TB treatment, increases the risk of DVT (Relative Risk: 4.7, 95\% CI 2.9-7.9) compared with other regimens, especially the first two weeks of treatment $[81,83]$.

VTE prevalence is higher in patients with TB. Dentan et al. [81] conducted a large database retrospective study with 27,659,947 TB admissions, and reported a VTE prevalence of $2.1 \%(95 \%$ CI $1.6-2.6 \%)$ in TB patients. Tuberculosis could independently predict VTE with an OR of 1.6 (95\% CI 1.2-2.0), close to VTE risk from neoplasia in MEDENOX [84] study (OR: 1.6, 95\% CI 0.9-2.8) (Table 4). A meta-analysis revealed that the VTE, PE and DVT prevalence among patients with active TB was 3.5\% (95\% CI 2.2-5.2) among 16,190 participants, 5.8\% (95\% CI 2.2-10.7) among 5512 participants and 1.3\% (95\% CI 0.0-4.1) among 12,928 participants, respectively [5]. The OR for VTE, PE and DVT in these patients were 2.9 (95\% CI 2.3-3.7), 3.6 (95\% CI 2.5-5.1) and 2.5 (95\% CI 1.8-3.4), respectively [5] (Table 4). The increased prevalence of PE compared to DVT is probably affected by the increased frequency of CT performed in TB patients but still seems to be 4-8 times higher than the general population, suggesting that patients with active TB are undoubtedly at increased risk of thrombosis [5].

Borjas-Howard et al. [78] studied the risk of VTE in 750 patients, of which $18(2.4 \%$, 95\% CI 1.4-3.8) suffered a VTE event. The median age at the time of VTE diagnosis was 42 years and 13 out of 18 VTE events happened in the time window of two weeks before the anti-TB treatment initiation.

The use of VKA in TB patients experiencing a thromboembolic event can be complicated by drug interactions and especially by rifampicin, which is used as a first-line drug for TB. Warfarin is a racemic mixture of both $\mathrm{R}$ and $\mathrm{S}$ enantiomeres. The $\mathrm{R}$ enantiomer is less potent than the $S$, and has a longer half-life. $R$ warfarin is metabolized by the enzymes cytochrome P450 (CYP450), in particular, CYP 1A2 and CYP 3A4, while S warfarin is metabolized by CYP 2C9 [85]. Rifampicin is a potent and non-specific inducer of the CYP450 enzyme system, and especially a recognized inducer of CYP 3A4, enhancing the metabolism of both enantiomeres. Rifampicin accelerates warfarin's clearance, resulting in decreased anticoagulant effect and difficulty in achieving the therapeutic INR level. In a study by Maina et al. [85] of 10 patients receiving both rifampicin and warfarin, the median TTR (Time in Therapeutic Range) was 47\% compared to the TTR for those not treated with rifampicin which was $62 \%$. In another study, the median TTR was only $33 \%$ [86]. In such cases, abruptly discontinuing rifampicin before the completion of TB treatment is potentially hazardous. Failing achieving the appropriate TTR may result in residual clots and potentially in chronic thromboembolic pulmonary hypertension. DOACs could be an 
alternative for anticoagulation. However, data on their efficacy and safety in such cases are only a few [87].

Mortality of concomitant active TB and VTE is reported to be about $15 \%$, while mortality from isolated TB or VTE is $2.7 \%$ or $2.5 \%$, respectively [81]. VTE was independently associated with mortality (OR: $3.9,95 \%$ CI 1.9-8.1) in TB patients.

To sum, TB is a prothrombotic disease. HIV co-infection and even TB treatment must raise awareness in managing these patients. Interaction between rifampicin and warfarin amplifies the need for further research in the use of DOACs in TB cases.

6. In Situ Thrombosis of the Pulmonary Arteries: Another Piece to the Puzzle of Acute VTE in Patients with Chronic Inflammatory Lung Diseases?

Table 1 summarizes the PE, DVT, and total VTE prevalence in the most common chronic airway and parenchymal inflammatory lung diseases. All of the studies reviewed here support the hypothesis that patients with chronic inflammatory lung diseases are at increased risk of a first episode of PE as well as recurrent episodes of PE rather than DVT, and greater risk of mortality [88].

The increased frequency of chest imaging in patients with pulmonary diseases may lead to detection biases causing associations to be larger for PE than DVT. However, PE without leg thrombosis has been reported in up to $50 \%$ of PE patients [10]. A pelvic or abdominal thrombosis using magnetic resonance angiography was detected only in $29 \%$ of patients with acute PE $[89,90]$. No peripheral clot was found in $56 \%$ of patients with a first PE episode, using magnetic resonance direct thrombus imaging, a method with high sensitivity and specificity of $98 \%$ and $96 \%$, respectively, that detects a clot for up to 6 months based on the transformation of hemoglobin into methemoglobin $[90,91]$. The authors in that study hypothesized that the clot could be of cardiac origin. However, no patient had signs consistent with heart failure (upon physical examination) and only two out of 55 patients with PE and no DVT had atrial fibrillation, making this assumption unlikely. Another possible explanation could be that the whole clot was completely dislodged from its primary position and ended up in pulmonary arteries. This theory seems unlikely for all the missing cases of DVT as it is not consistent with the data of post-mortem studies.

Hence, an occlusion of pulmonary arteries is not always due to embolism but might be an in-situ thrombosis, as here suggested. The same conditions that lead to the formation of the clot in peripheral sites might also lead to the primary clot formation in pulmonary arteries in cases of a chronic inflammatory lung disease.

\section{Conclusions}

The presence of chronic inflammatory lung diseases, such as asthma, COPD, ILDs, or active TB, increases the risk of VTE, especially PE, compared to the general population. High suspicion is needed to diagnose a thrombotic event early as the clinical presentation inevitably overlaps with respiratory disorders. PE risk increases with disease severity. The elevated inflammatory burden during disease exacerbations seems to predispose to VTE events correlated with increased mortality risk. Hospitalized patients should be considered for thromboprophylaxis administration, given the presence of additional risk factors during hospitalization such as immobilization, respiratory failure, and use of central venous catheters. The corticosteroid administration in asthma and COPD independently increases the risk of VTE, while TB treatment with rifampicin requires anticoagulant treatment with warfarin. This combination of findings provides some support for the conceptual premise that connections exist between VTE and chronic lung inflammatory comorbidities. Hence, it could conceivably be hypothesized that VTE patients should be asked for lung comorbidities before determining the duration of anticoagulant therapy. However, further research should be undertaken to understand the underlying pathophysiology of in situ or de novo thrombosis in those patients. 
Author Contributions: Conceptualization, O.S.K.; writing - original draft preparation, G.K.; writingreview and editing, O.S.K.; supervision, K.I.G. and O.S.K. All authors have read and agreed to the published version of the manuscript.

Funding: This research received no external funding.

Institutional Review Board Statement: Not applicable.

Informed Consent Statement: Not applicable.

Data Availability Statement: All data generated or analysed during this study are included in this published article.

Conflicts of Interest: The authors declare no conflict of interest.

\section{References}

1. Konstantinides, S.V.; Meyer, G.; Becattini, C.; Bueno, H.; Geersing, G.J.; Harjola, V.P.; Huisman, M.V.; Humbert, M.; Jennings, C.S.; Jiménez, D.; et al. The Task Force for the diagnosis and management of acute pulmonary embolism of the European Society of Cardiology (ESC). 2019 ESC Guidelines for the diagnosis and management of acute pulmonary embolism developed in collaboration with the European Respiratory Society (ERS): The Task Force for the diagnosis and management of acute pulmonary embolism of the European Society of Cardiology (ESC). Eur. Respir J. 2019, 54, 1901647. [PubMed]

2. Fedullo, P.F.; Tapson, V.F. Clinical practice. The evaluation of suspected pulmonary embolism. N. Engl. J. Med. 2003, 349, 1247-1256. [CrossRef] [PubMed]

3. Barco, S.; Mahmoudpour, S.H.; Valerio, L.; Klok, F.A.; Münzel, T.; Middeldorp, S.; Ageno, W.; Cohen, A.T.; Hunt, B.J.; Konstantinides, S.V. Trends in mortality related to pulmonary embolism in the European Region, 2000-2015: Analysis of vital registration data from the WHO Mortality Database. Lancet Respir. Med. 2020, 8, 277-287. [CrossRef]

4. Di Nisio, M.; van Es, N.; Büller, H.R. Deep vein thrombosis and pulmonary embolism. Lancet 2016, 388, 3060-3073. [CrossRef]

5. Danwang, C.; Bigna, J.J.; Awana, A.P.; Nzalie, R.N.; Robert, A. Global epidemiology of venous thromboembolism in people with active tuberculosis: A systematic review and meta-analysis. J. Thromb. Thrombolysis. 2021, 51, 502-512. [CrossRef]

6. Vazquez-Garza, E.; Jerjes-Sanchez, C.; Navarrete, A.; Joya-Harrison, J.; Rodriguez, D. Venous thromboembolism: Thrombosis, inflammation, and immunothrombosis for clinicians. J. Thromb. Thrombolysis. 2017, 44, 377-385. [CrossRef]

7. Branchford, B.R.; Carpenter, S.L. The Role of Inflammation in Venous Thromboembolism. Front. Pediatr. 2018, 6, 142. [CrossRef]

8. Schimanski, S.; Linnemann, B.; Luxembourg, B.; Seifried, E.; Jilg, W.; Lindhoff-Last, E.; Schambeck, C.M. Cytomegalovirus infection is associated with venous thromboembolism of immunocompetent adults-a case-control study. Ann. Hematol. 2012, 91, 597-604. [CrossRef]

9. Valerio, L.; Riva, N. Head, Neck, and Abdominopelvic Septic Thrombophlebitis: Current Evidence and Challenges in Diagnosis and Treatment. Hamostaseologie 2020, 40, 301-310. [CrossRef]

10. Bray, M.A.; Sartain, S.E.; Gollamudi, J.; Rumbaut, R.E. Microvascular thrombosis: Experimental and clinical implications. Transl. Res. 2020, 225, 105-130. [CrossRef]

11. Green, C.E.; Turner, A.M. The role of the endothelium in asthma and chronic obstructive pulmonary disease (COPD). Respir. Res. 2017, 18, 20. [CrossRef]

12. Stockley, R.A. Neutrophils and the pathogenesis of COPD. Chest 2002, 121, 151S-155S. [CrossRef]

13. Amsellem, V.; Gary-Bobo, G.; Marcos, E.; Maitre, B.; Chaar, V.; Validire, P.; Stern, J.B.; Noureddine, H.; Sapin, E.; Rideau, D.; et al. Telomere dysfunction causes sustained inflammation in chronic obstructive pulmonary disease. Am. J. Respir. Crit. Care Med. 2011, 184, 1358-1366. [CrossRef]

14. Dejana, E.; Lampugnani, M.G. Endothelial cell transitions. Science 2018, 362, 746-747. [CrossRef] [PubMed]

15. Eapen, M.S.; Lu, W.; Gaikwad, A.V.; Bhattarai, P.; Chia, C.; Hardikar, A.; Haug, G.; Sohal, S.S. Endothelial to mesenchymal transition: A precursor to post-COVID-19 interstitial pulmonary fibrosis and vascular obliteration? Eur. Respir. J. 2020, 56, 2003167. [CrossRef]

16. Racanelli, A.C.; Kikkers, S.A.; Choi, A.M.K.; Cloonan, S.M. Autophagy and inflammation in chronic respiratory disease. Autophagy 2018, 14, 221-232. [CrossRef] [PubMed]

17. Chung, W.S.; Lin, C.L.; Ho, F.M.; Li, R.Y.; Sung, F.C.; Kao, C.H.; Yeh, J.J. Asthma increases pulmonary thromboembolism risk: A nationwide population cohort study. Eur. Respir. J. 2014, 43, 801-807. [CrossRef]

18. Lee, P.H.; Fu, P.K. Pulmonary Embolism and Severe Asthma: Case Report and Literature Review. Medicina 2019, 55, 647. [CrossRef]

19. Hashimoto, T.; Ando, M.; Kan, T.; Fujishima, N.; Yamasue, M.; Komiya, K.; Umeki, K.; Nureki, S.I.; Kadota, J.I. Asthma Exacerbation Coincident with Saddle Pulmonary Embolism and Paradoxical Embolism. Tohoku J. Exp. Med. 2019, 248, $137-141$. [CrossRef] [PubMed]

20. de Boer, J.D.; Majoor, C.J.; van 't Veer, C.; Bel, E.H.; van der Poll, T. Asthma and coagulation. Blood 2012, 119, 3236-3244. [CrossRef]

21. Yeh, J.J.; Wang, Y.C.; Kao, C.H. Asthma-Chronic Obstructive Pulmonary Disease Overlap Syndrome Associated with Risk of Pulmonary Embolism. PLOS ONE 2016, 11, e0162483. 
22. Corbett, V.; Hassouna, H.; Girgis, R. In situ thrombosis of the pulmonary arteries: An emerging new perspective on pulmonary embolism. Med. Student Res. J. 2015, 4, 54-58.

23. Majoor, C.J.; Kamphuisen, P.W.; Zwinderman, A.H.; Ten Brinke, A.; Amelink, M.; Rijssenbeek-Nouwens, L.; Sterk, P.J.; Büller, H.R.; Bel, E.H. Risk of deep vein thrombosis and pulmonary embolism in asthma. Eur. Respir. J. 2013, 42, 655-661. [CrossRef]

24. Zöller, B.; Pirouzifard, M.; Memon, A.A.; Sundquist, J.; Sundquist, K. Risk of pulmonary embolism and deep venous thrombosis in patients with asthma: A nationwide case-control study from Sweden. Eur. Respir. J. 2017, 49, 1601014. [CrossRef] [PubMed]

25. Johannesdottir, S.A.; Horváth-Puhó, E.; Dekkers, O.M.; Cannegieter, S.C.; Jørgensen, J.O.; Ehrenstein, V.; Vandenbroucke, J.P.; Pedersen, L.; Sørensen, H.T. Use of glucocorticoids and risk of venous thromboembolism: A nationwide population-based case-control study. JAMA Intern. Med. 2013, 173, 743-752. [CrossRef]

26. Stuijver, D.J.F.; Majoor, C.J.; van Zaane, B.; Souverein, P.C.; de Boer, A.; Dekkers, O.M.; Büller, H.R.; Gerdes, V.E.A. Use of oral glucocorticoids and the risk of pulmonary embolism: A population-based case-control study. Chest 2013, 143, 1337-1342. [CrossRef]

27. Alzghoul, B.N.; Reddy, R.; Chizinga, M.; Innabi, A.; Zou, B.; Papierniak, E.S.; Faruqi, I. Pulmonary Embolism in Acute Asthma Exacerbation: Clinical Characteristics, Prediction Model and Hospital Outcomes. Lung 2020, 198, 661-669. [CrossRef] [PubMed]

28. Sneeboer, M.M.S.; Majoor, C.J.; de Kievit, A.; Meijers, J.C.M.; van der Poll, T.; Kamphuisen, P.W.; Bel, E.H. Prothrombotic state in patients with severe and prednisolone-dependent asthma. J. Allergy Clin. Immunol. 2016, 137, 1727-1732. [CrossRef]

29. Global Initiative for Chronic Obstructive Lung Disease (GOLD), Global Strategy for The Diagnosis, Management, And Prevention of Chronic Obstructive Pulmonary Disease. 2020. Available online: https://goldcopd.org/wp-content/uploads/2019/12/ GOLD-2020-FINAL-ver1.2-03Dec19_WMV.pdf (accessed on 3 March 2021).

30. Hassen, M.F.; Tilouche, N.; Jaoued, O.; Elatrous, S. Incidence and Impact of Pulmonary Embolism During Severe COPD Exacerbation. Respir. Care 2019, 64, 1531-1536. [CrossRef]

31. Fogarty, A.W.; Lewis, S.A.; McKeever, T.M.; Lowe, G.D.; Clark, L.; Britton, J. The association between blood coagulation activity and lung function: A population-based study. PLoS ONE 2010, 5, e15014. [CrossRef] [PubMed]

32. Kubota, Y.; London, S.J.; Cushman, M.; Chamberlain, A.M.; Rosamond, W.D.; Heckbert, S.R.; Zakai, N.; Folsom, A.R. Lung function, respiratory symptoms and venous thromboembolism risk: The Atherosclerosis Risk in Communities Study. J. Thromb. Haemost 2016, 14, 2394-2401. [CrossRef]

33. Juul, K.; Tybjaerg-Hansen, A.; Mortensen, J.; Lange, P.; Vestbo, J.; Nordestgaard, B.G. Factor V leiden homozygosity, dyspnea, and reduced pulmonary function. Arch. Intern. Med. 2005, 165, 2032-2036. [CrossRef]

34. Cao, Y.Q.; Dong, L.X.; Cao, J. Pulmonary Embolism in Patients with Acute Exacerbation of Chronic Obstructive Pulmonary Disease. Chin. Med. J. Engl. 2018, 131, 1732-1737. [CrossRef] [PubMed]

35. Rizkallah, J.; Man, S.F.P.; Sin, D.D. Prevalence of pulmonary embolism in acute exacerbations of COPD: A systematic review and metaanalysis. Chest 2009, 135, 786-793. [CrossRef]

36. Pourmand, A.; Robinson, H.; Mazer-Amirshahi, M.; Pines, J.M. Pulmonary Embolism Among Patients With Acute Exacerbation Of Chronic Obstructive Pulmonary Disease: Implications For Emergency Medicine. J. Emerg. Med. 2018, 55, 339-346. [CrossRef] [PubMed]

37. Aleva, F.E.; Voets, L.W.; Simons, S.O.; de Mast, Q.; van der Ven, A.J.A.M.; Heijdra, Y.F. Prevalence and Localization of Pulmonary Embolism in Unexplained Acute Exacerbations of COPD: A Systematic Review and Meta-analysis. Chest 2017, 151, 544-554. [CrossRef]

38. Dentali, F.; Pomero, F.; Micco, P.D.; La Regina, M.; Landini, F.; Mumoli, N.; Pieralli, F.; Giorgi-Pierfranceschi, M.; Re, R.; Vitale, J.; et al. Prevalence and risk factors for pulmonary embolism in patients with suspected acute exacerbation of COPD: A multi-center study. Eur. J. Intern. Med. 2020, 80, 54-59. [CrossRef] [PubMed]

39. Bertoletti, L. The paradoxical association between pulmonary embolism and COPD. Eur. Respir. J. 2017, 50, 1700959. [CrossRef]

40. Kahn, S.R.; Lim, W.; Dunn, A.S.; Cushman, M.; Dentali, F.; Akl, E.A.; Cook, D.J.; Balekian, A.A.; Klein, R.C.; Le, H.; et al. Prevention of VTE in nonsurgical patients: Antithrombotic Therapy and Prevention of Thrombosis, 9th ed: American College of Chest Physicians Evidence-Based Clinical Practice Guidelines. Chest 2012, 141, e195S-e226S. [CrossRef]

41. Park, H. Pulmonary embolism is more prevalent than deep vein thrombosis in cases of chronic obstructive pulmonary disease and interstitial lung diseases. Springerplus 2016, 5, 1777. [CrossRef]

42. Gunen, H.; Gulbas, G.; In, E.; Yetkin, O.; Hacievliyagil, S.S. Venous thromboemboli and exacerbations of COPD. Eur. Respir. J. 2010, 35, 1243. [CrossRef] [PubMed]

43. Akpinar, E.E.; Hoşgün, D.; Akpinar, S.; Ataç, G.K.; Doğanay, B.; Gülhan, M. Incidence of pulmonary embolism during COPD exacerbation. J. Bras. Pneumol 2014, 40, 38-45. [CrossRef] [PubMed]

44. Fraisse, F.; Holzapfel, L.; Couland, J.M.; Simonneau, G.; Bedock, B.; Feissel, M.; Herbecq, P.; Pordes, R.; Poussel, J.F.; Roux, L. Nadroparin in the prevention of deep vein thrombosis in acute decompensated COPD. The Association of Non-University Affiliated Intensive Care Specialist Physicians of France. Am. J. Respir. Crit. Care Med. 2000, 161, 1109-1114. [CrossRef]

45. Choi, K.J.; Cha, S.I.; Shin, K.M.; Lee, J.; Hwangbo, Y.; Yoo, S.S.; Lee, J.; Lee, S.Y.; Kim, C.H.; Park, J.Y.; et al. Prevalence and predictors of pulmonary embolism in Korean patients with exacerbation of chronic obstructive pulmonary disease. Respiration 2013, 85, 203-209. [CrossRef] [PubMed]

46. Ra, S.W.; Sin, D.D. Should We Screen for Pulmonary Embolism in Severe COPD Exacerbations? Not Just Yet, Primum Non Nocere. Chest 2017, 151, 523-524. [CrossRef] 
47. Tuder, R.M.; Cool, C.D. Pulmonary Arteries and Microcirculation in COPD With Pulmonary Hypertension: Bystander or Culprit? Chest 2019, 156, 4-6. [CrossRef]

48. Bazan, I.S.; Fares, W.H. Hypercoagulability in Pulmonary Hypertension. Clin. Chest Med. 2018, 39, 595-603. [CrossRef] [PubMed]

49. Le Mao, R.; Tromeur, C.; Bazire, A.; Gouillou, M.; Guegan, M.; Lacut, K.; Delluc, A.; Mottier, D.; Leroyer, C.; Couturaud, F. Risk of recurrent venous thromboembolism in COPD patients: Results from a prospective cohort study. Eur. Respir. J. 2017, 50, 1700094. [CrossRef]

50. Antoniou, K.M.; Margaritopoulos, G.A.; Tomassetti, S.; Bonella, F.; Costabel, U.; Poletti, V. Interstitial lung disease. Eur. Respir. Rev. 2014, 23, 40-54. [CrossRef] [PubMed]

51. Sgalla, G.; Biffi, A.; Richeldi, L. Idiopathic pulmonary fibrosis: Diagnosis, epidemiology and natural history. Respirology 2016, 21, 427-437. [CrossRef]

52. Margaritopoulos, G.A.; Kokosi, M.A.; Wells, A.U. Diagnosing complications and co-morbidities of fibrotic interstitial lung disease. Expert. Rev. Respir. Med. 2019, 13, 645-658. [CrossRef] [PubMed]

53. Keane, M.P.; Arenberg, D.A.; Lynch, J.P., 3rd; Whyte, R.I.; Iannettoni, M.D.; Burdick, M.D.; Wilke, C.A.; Morris, S.B.; Glass, M.C.; DiGiovine, B.; et al. The CXC chemokines, IL-8 and IP-10, regulate angiogenic activity in idiopathic pulmonary fibrosis. J. Immunol. 1997, 159, 1437-1443.

54. Renzoni, E.A.; Walsh, D.A.; Salmon, M.; Wells, A.U.; Sestini, P.; Nicholson, A.G.; Veeraraghavan, S.; Bishop, A.E.; Romanska, H.M.; Pantelidis, P.; et al. Interstitial vascularity in fibrosing alveolitis. Am. J. Respir. Crit. Care Med. 2003, 167, 38-43. [CrossRef] [PubMed]

55. Cosgrove, G.P.; Brown, K.K.; Schiemann, W.P.; Serls, A.E.; Parr, J.E.; Geraci, M.W.; Schwarz, M.I.; Cool, C.D.; Worthen, G.S. Pigment epithelium-derived factor in idiopathic pulmonary fibrosis: A role in aberrant angiogenesis. Am. J. Respir. Crit. Care Med. 2004, 170, 242-251. [CrossRef] [PubMed]

56. Hernández-Rodríguez, N.A.; Cambrey, A.D.; Harrison, N.K.; Chambers, R.C.; Gray, A.J.; Southcott, A.M.; duBois, R.M.; Black, C.M.; Scully, M.F.; McAnulty, R.J. Role of thrombin in pulmonary fibrosis. Lancet 1995, 346, 1071-1073. [CrossRef]

57. Alagha, K.; Secq, V.; Pahus, L.; Sofalvi, T.; Palot, A.; Bourdin, A.; Chanez, P. We should prohibit warfarin in idiopathic pulmonary fibrosis. Am. J. Respir. Crit. Care Med. 2015, 191, 958-960. [CrossRef] [PubMed]

58. Imokawa, S.; Sato, A.; Hayakawa, H.; Kotani, M.; Urano, T.; Takada, A. Tissue factor expression and fibrin deposition in the lungs of patients with idiopathic pulmonary fibrosis and systemic sclerosis. Am. J. Respir. Crit. Care Med. 1997, 156, 631-636. [CrossRef] [PubMed]

59. Kobayashi, H.; Gabazza, E.C.; Taguchi, O.; Wada, H.; Takeya, H.; Nishioka, J.; Yasui, H.; Kobayashi, T.; Hataji, O.; Suzuki, K.; et al. Protein C anticoagulant system in patients with interstitial lung disease. Am. J. Respir. Crit. Care Med. 1998, 157, 1850-1854. [CrossRef]

60. Olman, M.A.; Mackman, N.; Gladson, C.L.; Moser, K.M.; Loskutoff, D.J. Changes in procoagulant and fibrinolytic gene expression during bleomycin-induced lung injury in the mouse. J. Clin. Investig. 1995, 96, 1621-1630. [CrossRef] [PubMed]

61. Navaratnam, V.; Fogarty, A.W.; McKeever, T.; Thompson, N.; Jenkins, G.; Johnson, S.R.; Dolan, G.; Kumaran, M.; Pointon, K.; Hubbard, R.B. Presence of a prothrombotic state in people with idiopathic pulmonary fibrosis: A population-based case-control study. Thorax 2014, 69, 207-215. [CrossRef]

62. Sprunger, D.B.; Olson, A.L.; Huie, T.J.; Fernandez-Perez, E.R.; Fischer, A.; Solomon, J.J.; Brown, K.K.; Swigris, J.J. Pulmonary fibrosis is associated with an elevated risk of thromboembolic disease. Eur. Respir. J. 2012, 39, 125-132. [CrossRef]

63. Hubbard, R.B.; Smith, C.; Le Jeune, I.; Gribbin, J.; Fogarty, A.W. The association between idiopathic pulmonary fibrosis and vascular disease: A population-based study. Am. J. Respir. Crit. Care Med. 2008, 178, 1257-1261. [CrossRef]

64. Dalleywater, W.; Powell, H.A.; Fogarty, A.W.; Hubbard, R.B.; Navaratnam, V. Venous thromboembolism in people with idiopathic pulmonary fibrosis: A population-based study. Eur. Respir. J. 2014, 44, 1714-1715. [CrossRef] [PubMed]

65. Boonpheng, B.; Ungprasert, P. Risk of venous thromboembolism in patients with idiopathic pulmonary fibrosis: A systematic review and meta-analysis. Sarcoidosis Vasc. Diffuse Lung Dis. 2018, 35, 109-114. [PubMed]

66. Sode, B.F.; Dahl, M.; Nielsen, S.F.; Nordestgaard, B.G. Venous thromboembolism and risk of idiopathic interstitial pneumonia: A nationwide study. Am. J. Respir. Crit. Care Med. 2010, 181, 1085-1092. [CrossRef] [PubMed]

67. Luo, Q.; Xie, J.; Han, Q.; Tang, C.; Chen, X.; Wu, L.; Chen, R. Prevalence of venous thromboembolic events and diagnostic performance of the wells score and revised geneva scores for pulmonary embolism in patients with interstitial lung disease: A prospective study. Heart Lung Circ. 2014, 23, 778-785. [CrossRef] [PubMed]

68. Noth, I.; Anstrom, K.J.; Calvert, S.B.; de Andrade, J.; Flaherty, K.R.; Glazer, C.; Kaner, R.J.; Olman, M.A. Idiopathic Pulmonary Fibrosis Clinical Research Network (IPFnet). A placebo-controlled randomized trial of warfarin in idiopathic pulmonary fibrosis. Am. J. Respir. Crit. Care Med. 2012, 186, 88-95. [CrossRef]

69. Ungprasert, P.; Srivali, N.; Wijarnpreecha, K.; Thongprayoon, C. Sarcoidosis and risk of venous thromboembolism: A systematic review and meta-analysis. Sarcoidosis. Vasc. Diffuse Lung Dis. 2015, 32, 182-187.

70. Ungprasert, P.; Crowson, C.S.; Matteson, E.L. Association of Sarcoidosis with Increased Risk of VTE: A Population-Based Study, 1976 to 2013. Chest 2017, 151, 425-430. [CrossRef]

71. European Lung White Book. European Respiratory Society. Available online: www.erswhitebook.org/chapters/tuberculosis/ (accessed on 3 March 2021). 
72. Turken, O.; Kunter, E.; Sezer, M.; Solmazgul, E.; Cerrahoglu, K.; Bozkanat, E.; Ozturk, A.; Ilvan, A. Hemostatic changes in active pulmonary tuberculosis. Int. J. Tuberc. Lung Dis. 2002, 6, 927-932.

73. Robson, S.C.; White, N.W.; Aronson, I.; Woollgar, R.; Goodman, H.; Jacobs, P. Acute-phase response and the hypercoagulable state in pulmonary tuberculosis. Br. J. Haematol. 1996, 93, 943-949. [CrossRef] [PubMed]

74. Feng, Y.; Dorhoi, A.; Mollenkopf, H.J.; Yin, H.; Dong, Z.; Mao, L.; Zhou, J.; Bi, A.; Weber, S.; Maertzdorf, J.; et al. Platelets direct monocyte differentiation into epithelioid-like multinucleated giant foam cells with suppressive capacity upon mycobacterial stimulation. J. Infect. Dis. 2014, 210, 1700-1710. [CrossRef]

75. Ogawa, T.; Uchida, H.; Kusumoto, Y.; Mori, Y.; Yamamura, Y.; Hamada, S. Increase in tumor necrosis factor alpha- and interleukin6-secreting cells in peripheral blood mononuclear cells from subjects infected with Mycobacterium tuberculosis. Infect. Immun. 1991, 59, 3021-3025. [CrossRef]

76. Hussain, R.; Shiratsuchi, H.; Phillips, M.; Ellner, J.; Wallis, R.S. Opsonizing antibodies (IgG1) up-regulate monocyte proinflammatory cytokines tumour necrosis factor-alpha (TNF-alpha) and IL-6 but not anti-inflammatory cytokine IL-10 in mycobacterial antigen-stimulated monocytes-implications for pathogenesis. Clin. Exp. Immunol. 2001, 123, 210-218. [CrossRef]

77. Kothari, H.; Rao, L.V.M.; Vankayalapati, R.; Pendurthi, U.R. Mycobacterium tuberculosis infection and tissue factor expression in macrophages. PLoS ONE 2012, 7, e45700. [CrossRef] [PubMed]

78. Borjas-Howard, J.F.; Bierman, W.F.W.; Meijer, K.; van der Werf, T.S.; Tichelaar, Y.I.G.V. Venous thrombotic events in patients admitted to a tuberculosis centre. QJM 2017, 110, 215-218. [CrossRef] [PubMed]

79. Shitrit, D.; Izbicki, G.; Shitrit, A.B.; Raz, M.; Sulkes, J.; Kramer, M.R. Normal D-dimer levels in patients with latent tuberculosis infection. Blood Coagul. Fibrinolysis 2005, 16, 85-87. [CrossRef] [PubMed]

80. Teklu, T.; Wondale, B.; Taye, B.; Hailemariam, M.; Bekele, S.; Tamirat, M.; Zewude, A.; Mohamed, T.; Medhin, G.; Legesse, M.; et al. Differences in plasma proteomes for active tuberculosis, latent tuberculosis and non-tuberculosis mycobacterial lung disease patients with and without ESAT-6/CFP10 stimulation. Proteome Sci. 2020, 18, 10. [CrossRef] [PubMed]

81. Dentan, C.; Epaulard, O.; Seynaeve, D.; Genty, C.; Bosson, J.L. Active tuberculosis and venous thromboembolism: Association according to international classification of diseases, ninth revision hospital discharge diagnosis codes. Clin. Infect. Dis. 2014, 58, 495-501. [CrossRef]

82. Marjani, M.; Tabarsi, P.; Baghaei, P.; Shamaei, M.; Gorgi Biani, P.; Mansouri, D.; Masjedi, M.R.; Velayati, A.A. Incidence of thromboembolism in hospitalized patients with tuberculosis and associated risk factors. Arch. Clin. Infect. Dis. 2012, 7, 56-59. [CrossRef]

83. White, N.W. Venous thrombosis and rifampicin. Lancet 1989, 2, 434-435. [CrossRef]

84. Alikhan, R.; Cohen, A.T.; Combe, S.; Samama, M.M.; Desjardins, L.; Eldor, A.; Janbon, C.; Leizorovicz, A.; Olsson, C.G.; Turpie, A.G.; et al. Risk factors for venous thromboembolism in hospitalized patients with acute medical illness: Analysis of the MEDENOX Study. Arch. Intern. Med. 2004, 164, 963-968. [CrossRef] [PubMed]

85. Maina, M.W.; Pastakia, S.D.; Manji, I.; Kirui, N.; Kirwa, C.; Karwa, R. Describing the profile of patients on concurrent rifampin and warfarin therapy in western Kenya: A case series. Drugs R. D. 2013, 13, 191-197. [CrossRef]

86. Sekaggya, C.; Nalwanga, D.; Von Braun, A.; Nakijoba, R.; Kambugu, A.; Fehr, J.; Lamorde, M.; Castelnuovo, B. Challenges in achieving a target international normalized ratio for deep vein thrombosis among HIV-infected patients with tuberculosis: A case series. BMC Hematol. 2016, 16, 16. [CrossRef] [PubMed]

87. Fiore, M.; Maraolo, A.E.; Chiodini, P.; Cerchione, C.; Gentile, I.; Borgia, G.; Pace, M.C. Is Anticoagulation with Novel Oral Anticoagulants an Effective Treatment for Tuberculosis Patients not Achieving a Therapeutic Range with Vitamin K Antagonists? A Systematic Review. Cardiovasc. Hematol. Disord. Drug Targets 2017, 17, 105-110. [CrossRef]

88. Yamashita, Y.; Yoshikawa, Y.; Morimoto, T.; Amano, H.; Takase, T.; Hiramori, S.; Kim, K.; Oi, M.; Akao, M.; Kobayashi, Y.; et al. The association of recurrence and bleeding events with mortality after venous thromboembolism: From the COMMAND VTE Registry. Int. J. Cardiol. 2019, 292, 198-204. [CrossRef]

89. Marongiu, F.; Mameli, A.; Grandone, E.; Barcellona, D. Pulmonary Thrombosis: A Clinical Pathological Entity Distinct from Pulmonary Embolism? Semin. Thromb. Hemost. 2019, 45, 778-783. [CrossRef] [PubMed]

90. Stern, J.B.; Abehsera, M.; Grenet, D.; Friard, S.; Couderc, L.J.; Scherrer, A.; Stern, M. Detection of pelvic vein thrombosis by magnetic resonance angiography in patients with acute pulmonary embolism and normal lower limb compression ultrasonography. Chest 2002, 122, 115-121. [CrossRef]

91. van Langevelde, K.; Sramek, A.; Vincken, P.W.J.; van Rooden, J.K.; Rosendaal, F.R.; Cannegieter, S.C. Finding the origin of pulmonary emboli with a total-body magnetic resonance direct thrombus imaging technique. Haematologica 2013, 98, 309-315. [CrossRef] 